\title{
Socially Responsible Management as a Basis for Sound Business in the Family Firm
}

\author{
M. John Foster ${ }^{1}$
}

Published online: 20 June 2017

C The Author(s) 2017. This article is an open access publication

\begin{abstract}
This paper examines the proposition that adopting a socially responsible, or philanthropic, management posture is not antithetic to the capitalist business model but rather can be seen as a sound approach to the development of long-term sustainability in business in a modern business environment, wherein a strand of corporate social responsibility is one core aspect of the composite utility function of the modern business. We suggest further that for many of the prominent/significant examples of the successful adoption of a policy of informed benevolence in the management of employees that policy seems to be faith rooted - be that faith Christian, Buddhist, Jewish, Muslim or other. Indeed, even if one observed an organisation subject to an humanist or even atheistic based socially responsible management, one could see that as being rooted in that organisation's 'non-faith' faith, or ethical bubble. Our argument also gives the lie to the proposition, in currency in some circles, that the term 'business ethics' is an oxymoron. To underpin the argument we cite examples (/set out mini-cases, or a mixture of these) from a range of faith based traditions including, Buddhism, the Quaker-Christian tradition, Judaism and Islam.
\end{abstract}

Keywords CSR $\cdot$ Socially responsible management $\cdot$ Family $\cdot$ Faith rooted

\section{Introduction}

This paper examines the proposition that adopting a socially responsible, or philanthropic, style of management (SRM) posture is not of itself antithetic to the capitalist business model but rather can be seen as a sound approach to the development of long-term sustainability in business in a modern business environment, wherein a strand of corporate social responsibility is one core aspect of the composite utility function of the modern business. By socially responsible management, we mean a management approach which explicitly accepts the need

M. John Foster

foster@ kingston.ac.uk

1 Asia Business Research Centre, Kingston Business School, Kingston University, London, UK 
to treat employees in an equitable fashion, to have concern for the communities within which one's firm operates (both in terms of continuing commitment to offer employment and commitment not to foul the environment) and to behave considerately and ethically towards others with whom one trades, suppliers or customers. We suggest further that, for many of the prominent/significant examples of the successful adoption of a policy of informed benevolence in the management of employees, the policy seems to be faith rooted, especially in the context of the family firm - be that faith Christian, Buddhist, Jewish, Muslim or other. Indeed, even if one observed an organisation subject to an humanist or even atheistic based SRM, one could see that as being rooted in that organisation's 'non-faith' faith, or ethical bubble. This line of argument also gives the lie to the proposition that the term 'business ethics' is an oxymoron.

The most widespread underpinning philosophy of modern business worldwide is arguably neo-classical (micro-)economics, Hodgson (1993). Within that view of the world, most would accept that the prevailing core objective is the maximisation of one or more key economic variables such as profit and shareholder wealth. A more subtle understanding of this classic micro-economic view would include some sense of time in conjunction with those underlying indicators; for, it is of little value to the owners of most firms to have royal profit this year and bankruptcy next, although this has been the fate of some companies acquired by asset strippers! [Slater-Walker and Hanson were two prominent names in the UK in that field in the 1970s and according to Clegg et al. (2011, p. 368), they and their like were, "in many important respects the direct ancestors of today's private equity firms."] However, in more recent times - essentially the last 40 plus years - formal, corporate objectives have widened to include, at least to some degree, notions of corporate social responsibility (CSR). An early text setting out the case for CSR is Bowen (1953). This means that companies have at least biattribute objective functions, namely their key economic objective and some CSR driven objective. For many firms there is a sense that the former objective far outweighs the latter but at least the latter is now present, for big, listed firms because they are mandated to consider such issues in a number of western jurisdictions. However, many commentators are of the view that it is still quite common for companies' CSR objectives to be something of an 'add-on' feature rather than being a key underpinning philosophical tenet of the firm, see e.g. Prayukvong and Foster (2014), and at the extreme there are those who essentially buy in to the Friedmanite view that a firm's business should solely be "to make as much money for its stockholders as possible", Friedman (1962, p.133).

Does it have to be thus or can it make sense for the owners of a firm to build their business on foundations which include what, in modern parlance, might be termed key CSR objectives? In other words can CSR be one of the foundation stones of a firm rather than a reluctantly added side show? It is the position of this paper that such a foundation stone position can indeed work, delivering benefits not only to shareholders but also to employees, possibly customers and suppliers, and hence to the wider community within which the firm has its being. A key aspect of this CSR-type underpinning is its ethical nature and as such our position will also be that the sceptics who claim that the term 'business ethics' is an oxymoron, e.g. Allinson (2008) and Collins (1994), are wrong. This subordinate point to the main premise is included precisely because there are still those (such as the sources just cited) who argue the term to be an oxymoron, scarcely credible as it may be to some others that anyone still holds such a view in the twenty-first Century.

Interestingly, while the formal notion of CSR may be a post-1950 term, some key examples we shall call on of businesses which have been run on an ethical, socially responsible basis pre-date usage of the term CSR by well over half a century. Not only can one find examples of 
socially responsibly managed firms prior to the emergence of the formalised CSR literature after the second world war, there is also evidence of some leavening of the profit motive by moral principles in pre-twentieth Century economic writings. We shall explore this a little in the literature review below. Nevertheless, we should argue that the kind of embedded SRM practice we shall explore in this paper is by no means the norm even today. There remains a tension between the prevailing economic and social responsibility mantras relating to the firm. It is our view that the modal behaviour of firms is the pursuit of economic objectives centred on optimising an economic utility function, where marginal gains deliver super-normal profits (or economic rent) for shareholders, while following ethical or moral objectives less assiduously.

The empirical or evidence raising part of the paper will comprise descriptions, based on both secondary and primary sources, of seven family firms which have successfully pursued a socially responsible style of management. Our examples derive from the UK and SE Asia, but there may very well be excellent examples in other parts of the world of which we simply are unaware. One of the things we found was that, in all the cases we identified of firms exercising a socially responsible style of management, their very benevolence appeared to be faith-rooted, albeit the faith varied from firm to firm. However, it is not our proposition that all family or faith rooted firms are SRM adherents. There are examples of shocking behaviour by Christians [according to Fitzgerald (1999), even some Quaker owners were anything but socially responsible; he cites the Bryant brothers of Bryant and May matchmakers; and to a lesser degree the Clarks of Clarks Shoes fame], Jews [Rupert Maxwell's Mirror Group Newspapers], Muslims [e.g. the operators of the Bangladeshi garment factory whose Rana Plaza building collapsed killing and injuring dozens in Dacca on 24th April, 2013, see BBC (2014)] and Buddhists [e.g. "Brilliant" Clothing Company of Bangkok (a pseudonym) - this company had employees in the early 1990s who were 'off- payroll', and whose taxes and social security deductions, as experienced by the employees, did not make their way to the Government's coffers.]

Two things should be made clear before we look at the cases. Firstly, this is an exploratory, debative paper which examines the noted theme of the role socially responsible management, essentially in the setting of family run firms, may play as one of the foundations of the firm's philosophy rather than as an adjunct. For big firms in mature jurisdictions some such activity is now essentially required but also 'earns them brownie points'. As such the paper's end product is, in formal logic terms, an interesting conjecture, which attempts could then be made to support, or otherwise, by further detailed empirical study, in line with the need for replication or confirmation studies specified by Popperian principles of 'near proof' by virtue of non-refutation, as advocated by van Witteloostuijn (2016). In other words, this paper is not suitable reading matter for unreconstructed, empirical positivists, see for example Collis and Hussey (2003).

Secondly there is the question whether one is suggesting that the socially responsible approach to management being espoused is primarily a function of the size of a firm or its family ownership. The short answer is the latter, basically because family control allows the owners, if they so wish, to operate a multi-attribute utility function consonant with their faith beliefs and/or ethical posture. The evidence base, set out in the third section, is in essence a set of mini-cases (Yin 1994) chosen because of the juxtaposition in each of an active (in modern parlance) CSR programme alongside the firm's business strategy. The case firms vary in size from small, through medium to large. However, a key point is that all, even the large firms, were family controlled or directed at the point in their history highlighted in the case 
description, although it is becoming increasingly rare for big companies in the UK to be family-run. Two of the case firms, Cadburys and Rowntree, have since been absorbed by foreign multinationals, from the USA and Switzerland respectively. Some of the cases are based on primary data collection (the Tang Mo and Safis Solutions cases) while the others are based mainly on secondary sources. Before setting out the mini-cases, we now offer a brief scan of the literature by way of context setting.

\section{A Brief Background from the Literature}

In this section we briefly review some of the previously published papers which have intersected from some angle with the premises of this paper. We put the thought in that way because, in set theoretic terms (Halmos 1960), most have some intersection (overlap) with the content set of our own paper but only a partial intersection.

First off, Carroll and Shabana (2010) present a review of the arguments for, and against, the basic view that 'there can be a business case for CSR'. They suggest that such a case can be made provided the CSR programme is well shaped relative the character of the firm's business. In their words (p.96): "Mediating variables and situational contingencies affect the impact of CSR on firm financial performance. Therefore, the impact of CSR on firm financial performance is not always favorable. Rather, firms should understand the circumstances of the different CSR activities and pursue those activities that demonstrate a convergence between the firm's economic objectives and the social objectives of society. Only when firms are able to pursue CSR activities with the support of their stakeholders can there be a market for virtue and a business case for CSR." At least there is hope might be the conclusion here.

Lin (2010) looks at the place of CSR in China and finds a relatively embryonic state of play but one with some potential given time and commitment. According to Lin, the kind of CSR programmes currently visible in China are somewhat rule-driven in character and apply mainly to larger, and hence in the China context, non-family, businesses. The picture in China seems important to note if only because of that country's increasing importance in the global economy.

Sorenson et al. (2009, p.239) found supporting evidence for their proposals that, in family firms, "the presence of ethical norms further helps cultivate family social capital" and "as a resource ... family social capital is positively related to family firm performance." This is suggestive that such firms viewed through a different lens may well find a place for CSR activities, related as they often are to positive ethical positions. Indeed this is evidence to suggest that not only can an SRM focus co-exist with the capitalist agenda but also it can help to deliver good economic outcomes.

Looking at the family firm through the lens of an appropriate approach for them to strategic management, Sharma et al. (1997) conclude that those interested in family businesses should not assume that what may be good for the family is necessarily good for their business or vice versa. This they argue is because in relation to any decision there are often trade-offs between the needs of the family and the needs of the business. This might suggest that they would be sceptical about the likelihood of a successful blending of CSR and 'pure business objectives' in the family firm. However, they go on to advise that the actors should, "Seek to understand [these needs] in order to make decisions which are most likely to result in a desirable outcome mix." This suggests by turn that they see some cause for optimism given a degree of subtlety in how one might weave the CSR agenda into the firm's operation. 
Turning to the role and/or impact of religion in the business, we consider work relating to both Christian and Muslim workers. In a paper reporting a study whose subjects were Christians, Lynn et al. (2010, p.694) observed that, "people bring their entire selves to work." They claimed to find that work-faith integration not only affects people in themselves but also has an impact on their actions towards others, potentially delivering what we might term a degree of team synergy. Given that the subjects were Christians, it would seem reasonable to predict that such synergies would link well with a positive ethical approach to business.

Beekun and Badawi (2005) consider a normative view of Islamic business ethics. Put simply, they argue that if Muslims conform to the ethical standards which their faith sets out as the required norm for their lives, they will conduct their business in a highly ethical fashion. Thus, at least from a normative perspective, it follows that an Islamic rooted family firm should do ethical business with policies in place which might alternatively viewed be seen to comprise a strong CSR agenda at the heart of the business. Of course sadly we know that their hopes may be confounded as reference to Transparency International's CPI index will readily confirm, Transparency International (2014). We should also make the point that one might well expect that followers of the Judaic and Christian traditions would share the same or similar ethical ground to their Muslim brothers and sisters.

Focussing particularly on the small business sector, Spence and Rutherfoord (2001) proposed that there are four frames or lenses through which one may perceive the social perspective of the small business, linked to four differing priorities. The four priorities are profit-maximisation, subsistence, enlightened self-interest and a social view. If policy makers wish to influence the ethics of small firms, they need to be aware of this diversity of viewpoints and move beyond a picture of the small business owner-manager as a profit-maximising, rational economic entrepreneur and bring a wider set of possibilities, especially the social priority option, into focus.

In sum, these papers represent a body of work which might suggest that our proposition as outlined in the introduction is at least plausible. There are strands of work suggesting that family ownership, business size, faith beliefs of owners and appetite for ethics, be they faith rooted or humanist/secular, all have their contributions to make in the CSR adoption debate. As Zairi and Peters (2002) argue, in like fashion to our own line, it is time for social responsibility policies to be key drivers of the business enterprise not just nice 'appendages'. Moreover, there is some evidence that such an approach can actually be good for company profits or shareholder value.

Before moving on to the sequence of mini-cases which form the empirical base of the paper, we look back at some early economic writings. We referred to the neo-classical school of economics earlier. Of course for there to be a neo-classical school there had to be before that a classical school. As we shall see some of the key players of both of these schools felt themselves subject to moral or ethical constraints. That does not mean, however, that the everyday application of what are essentially economic ideas by businessmen have all been morally informed or underpinned. Were it to have been otherwise, then Friedman's (1962) famous position to which we have already referred would have had no relevance.

According to Stiegeler and Thomas (1976, p.59), "classical [economics may be] said to begin with the publication of Adam Smith's Wealth of Nations." Key figures in its development included Malthus, Ricardo (famous for his theory of comparative advantage) and McCulloch. Smith's most often quoted book is indeed the Wealth of Nations published in 1776 (Campbell et al. 1976) but he had actually published an earlier book entitled The Theory of Moral Sentiments in 1759 (Raphael and Stair 1978). From this we can see that Smith had at 
the very least some awareness of what we are calling SRM issues in this paper but Wealth of Nations cannot fairly be said to include any sense of a requirement that the pursuit of free market competition (a key aspect of his treatise) be underwritten by SRM principles. In fact he argued that in a freely competitive economy (where government's role was confined to safeguarding property rights, the maintenance of certain types of public works, such as roads, and national defence) the self interest of individuals would lead automatically to an efficient distribution of a society's resources. There is perhaps here a key distinction between the explication of theories, be they concerned with morality or economics, and their application by entrepreneurs or merchants. Many a businessman or firm has indeed pursued what they perceive as their self interest and it has often not included moral behaviours beyond basic adherence to the laws of the land, if that.

The movement on into the neo-classical school period has been characterised as the 'marginal revolution' (see for example Stiegeler and Thomas 1976). This school can be traced to about the 1870s and focussed on marginal analysis centred around objectives couched in terms of utility and profit maximisation. The eclectic, early adopters of this differential calculus based approach were Carl Menger (Austrian), William Stanley Jevons (English) and Marie Esprit Léon Walras (French). Their work was carried forward by others including Pareto, famous for his concept of Pareto optimality amongst other things, and Marshall. It is felt by some that Marshall's major textbook Principles of Economics, first published in 1890, is the early defining, accessible statement of the neo-classical school. In that he summarised matters fully this may be so but, as anyone who has actually read more than the odd paragraph will know, this is not a book for the faint hearted.

Interestingly, in the preface to his book Marshall (1890) writes, "The present treatise is an attempt to present a modern version of old doctrines with the aid of the new work, and with reference to the new problems, of our own age. .....and it is held that the Laws of Economics are statements of tendencies expressed in the indicative mood, and not ethical precepts in the imperative." He continues a little later, "But ethical forces are among those of which the economist has to take account. Attempts have indeed been made to construct an abstract science with regard to the actions of an "economic man," who is under no ethical influences and who pursues pecuniary gain warily and energetically, but mechanically and selfishly. But they have not been successful, nor even thoroughly carried out. For they have never really treated the economic man as perfectly selfish: no one could be relied on better to endure toil and sacrifice with the unselfish desire to make provision for his family; and his normal motives have always been tacitly assumed to include the family affections. But if they include these, why should they not include all other altruistic motives the action of which is so far uniform in any class at any time and place, that it can be reduced to general rule? There seems to be no reason; and in the present book normal action is taken to be that which may be expected, under certain conditions, from the members of an industrial group; and no attempt is made to exclude the influence of any motives, the action of which is regular, merely because they are altruistic."

Thus, like Smith a century or more earlier, Marshall is not unaware of the moral dimension. However, it is one thing to make caveats in the preface to a book on theory, it is another to persuade the businessmen of the day or the ensuing hundred years or so that they should adopt an SRM posture as the very foundation for their business. As Marshall (1920) himself wrote in the new preface for the 8th edition of his book: "But normal action falls into the background, when Trusts are striving for the mastery of a 
large market; when communities of interest are being made and unmade; and, above all, when the policy of any particular establishment is likely to be governed, not with a single eye to its own business success, but in subordination to some large stockexchange manœuvre, or some campaign for the control of markets."

In more recent times, one of the developments of theories of the firm has been the so-called behavioural theory of the firm, best known from the book by Cyert and March (1963), A Behavioural Theory of the Firm. The name might suggest an approach which could well have space for some element of SRM in the foundations of the behavioural model. Indeed there is no real obstacle to such but that is not in fact what their theory is about. It concerns how organizations function when managers have 'bounded (not full) rationality' (Simon 1955), there is disagreement on goals, and the environment is uncertain. This disagreement over goals typically occurs because all but the smallest firms effectively operate as coalitions of individuals or subgroups - such subgroups might include managers, shareholders, workers, suppliers and so on. Cyert and March argue that, faced with the trade-offs inherent in the competing objectives of their subgroups, real firms aim at 'satisficing' rather than maximizing their results, i.e. some groups may settle for outcomes which are "good enough" rather than demanding the best possible outcome relative to their own group's preferred utility function. Again there is no reason in principle why an SRM style foundation for a firm could not be built by the coalitions which comprise it but the model makes no requirement for such SRM activity.

A point of interest here is that Cyert and March (1963) note that the larger firm as a coalition of groups contrasts with the small firm where an individual entrepreneur or small group of people can act as they please and hence have no inherent need to satisfice. By the same token one may argue that they have the power to decide that they will build an SRM foundation for their business and accept that as a given constraint to whatever their preferred, output, utility function may be. This resonates with the stories in the case studies of smaller firms in the next section.

Finally, it is worth noting what the legal position can be, as enshrined in company law. In the UK, the Companies Act (2006, s.172 (1)) states that: "A director of a company must act in the way he considers, in good faith, would be most likely to promote the success of the company for the benefit of its members as a whole, and in doing so have regard to [various other matters]" including, "the desirability of the company maintaining a reputation for high standards of business conduct." Thus as has long been the case in UK company law, directors are required to manage their firm primarily to the benefit of the members (or shareholders). The initial duty under s.172 (1), is moderated only by the need to have regard to the needs of all members (i.e. not give preference to one sub-group over another) and the ensuing caveat to have due regard to various matters; but one must emphasise that the duty of care is only to have regard. Again one sees a distinction between the small firm, where the members and directors are one and the same, and the large firm, where typically there is a distinction. It is open to the directors of large firms to embed SRM principles into their business structure provided they are able to construct a convincing argument why such embedded policies will, in the long run, be to the economic benefit of the members or shareholders. If a shareholder or group of them object on the grounds that such policies are leading to a diminution of shareholder value (dividend stream and capital value) then the law would seem to be on their side. 


\section{Cases of Family Firms with an SRM Approach across Nations}

\section{A Thai Buddhist Firm - Tang Mo}

Tang Mo is a Thai firm based in what may be thought of as the outer, western suburbs of Bangkok, about 25 miles west of the city centre. They make apparel, mainly casual wear and the brand has very strong recognition in the Thai market. There are many apparel makers in Thailand and what distinguishes Tang Mo (its official name is Siam Hands Co Ltd) from many or even most of the others is the good quality of the working environment and conditions of service for its employees. Why is this so? The answer is that the couple who own and have developed the business believe that they must follow the Buddhist notion of trying to live a right life and reflect such in all parts of their lives, including the running of their business.

This has been described elsewhere as their pursuing a path of Buddhist economic action rather than the neo-classical economic path which is the common ground of most 'western' business, Prayukvong and Foster (2014). The notion of Buddhist economics (BE) was first proposed by Schumacher (1973) and is in essence a fusion between standard economics and the pursuit of Buddhist principles for life. In terms of the modern CSR debate one may say that Buddhist economics (BE) required the 'normal' economic process to be built on foundations which include core Buddhist ethics. These include: 'self' being interpreted as something which is not only oneself but also those other persons who are linked to you in the course of your social and working life; the centrality of the notion of the interconnectedness of society; and the need to do good not just accrue wealth for oneself. As a result, one can say that a firm managed to properly follow a BE path can be conceptualised as one having a multi-attribute utility function, based around non-commensurate output measures: economic benefits (output, sales, profit, etc..) on the one hand and social benefits to both consumers of its end products and its employees, on the other hand, not forgetting the owners who will reap personal wellbeing from the fact that they have delivered such benefits to their local or even national society. The approach does accept the need to operate effectively and efficiently in a standard economic sense, while possessing an in-built philosophical sense of social responsibility.

Wages at Tang Mo are fair (better than many in Thailand) but crucially are allied to better general working conditions and other benefits such as healthcare. The factory floor is not an unpleasant place, as found in some Asian sweatshops; one wall of the main workshop is mainly glass looking out of a green sward running down to the Tha Jean River, a smaller tributary of the Chaophraya astride which central Bangkok sits. The core production group of the workforce, after some work layout experiments, is now organised on a team basis where intra-group helping is possible, output targets are for the group and any bonuses earned are team based

As explained in Prayukvong and Foster (2014, p188): “Training in Tang Mo covers not only technical skills but also life skills. Various, life-skills training programmes are delivered for all employees; they are conducted by a renowned monk, their managers and employers. There is also a compulsory training course for all new-comers to build an understanding of Tang Mo's culture of brotherhood." When the author visited the site, the main thing which struck him was that there was a happy and relaxed atmosphere on the shopfloor.

So, we see a business run on commercial lines - it makes healthy profits but does not seek to 'maximise' profits to the exclusion of other matters - but with an underpinning of ethical principles and hence behaviours which are rooted in the religious beliefs of the owner-manager couple. In addition to trying to operate their core business in accordance with Buddhist 
economic principles, the co-owners also undertake training involving various external, social and community activities. These include organising training courses for community members from rural areas and for workers in other garment and clothing factories.

\section{Three Quaker-Christian Family Firms - Cadburys, Rowntrees and Peases}

There were many Quaker families engaged in the process of Britain's industrialisation in the 19th and early 20th centuries and at least some of them were notable for their adoption of social policies aimed at the welfare of their employees and their constituent communities which were entirely admirable. A useful summary of the background to and character of the Quaker approach to doing business is provided by Platts (2014).

Three families who were prominent in this matter of social affirmation were the Cadbury family (famous chocolate and soft-drink producers based in the Birmingham area), the Rowntrees (again in the confectionery business and based in York) and the Pease family who were engaged in industrial production (mining and railways) as well as banking in the Darlington area. The common features of all three of these family firms were: they were all Quaker Christians; they subscribed to a social agenda beyond the making of profit from their businesses; and they embedded those social policies within the core of their businesses, making them foundation stones rather than 'nice extras'. Sadly both Cadburys and Rowntrees have been taken over by foreign parents in the twenty-first century, Rowntrees by Swiss giant Nestlé in 1988 and Cadburys by US firm Kraft in 2009 - not entirely for the good it may be argued. For example, Kraft promised during its bid for Cadburys that there would be no factory closures and hence job losses in the "foreseeable future" but this pledge was broken within a few months of their bid succeeding. Rowntrees' philanthropic legacy still lives on however in the name of the family via the Joseph Rowntree Charitable Trust, one of three charitable enterprises which the said Joseph established in 1904 using approximately half of his then accrued wealth.

The Cadbury name is most commonly associated with notions of benevolence as a result of the establishment in 1897 of its Bournville model town near Birmingham. The lead initiator of this scheme was the then company chairman George C. Cadbury (1839-1922). In essence the purpose of the scheme was to create living space for the employees of Cadburys which was fit for modern living at the turn of the century. It could be described in one sense as enlightened self-interest by the firm in that, if it provided good quality accommodation and health care for its workers, they would be fit to do good work at the company's factories. Just as the Latin saying goes mens sana in corpore sano, so the principle here was men and women fit for work from a fit living area.

This however was by no means the first step by the Cadburys along a path to align economic performance and social welfare. As early as 1850, Cadburys' employees had enjoyed the following benefits:

- A lunch "hour" and refreshments provided by the company;

- An additional half day holiday per week (a 6 day working week was standard practice in Victorian times);

- Organised excursions on Saturday afternoons

- Time off to attend education classes, and later, compulsory education for all employees under 18 . 
As Morland (2009) points out this was contrary to the common business practice of the time. Two other points she makes are significant in the context of our propositions. Namely, "it was Quaker practice to shun the use of titles and all employees were referred to on a first name basis - including the Cadbury family", and, "sharing meals and prayers in the workplace was common practice."

Rowntrees were in a way quite similar. Their co- founder, essentially, again a prominent Quaker this time from York, Joseph Rowntree (1836-1925) aspired to not only produce top quality cocoa, chocolate and confectionary but also to ensure that the firm's employees would enjoy fair wages and high quality welfare benefits. The business thrived and grew until, "At its peak, Rowntree's was a town within a town, employing 14,000 people, though later the workforce was much reduced by mechanisation." (Rowntree, and Co: Chocolate Manufacturers, History of York, online as at 2014)

Meanwhile, forty miles north of York in Darlington, the Peases, who were one of several Quaker families who ran businesses, adopted some enlightened practices in terms of their employees and their families and made social benefit provisions for the wider community, schools and public leisure spaces amongst others. The Peases owned mines north of town; were instrumental in getting the area's steam powered railways started; and along with the Backhouse family operated Backhouse's Bank which funded much local industry. The Peases' mining portfolio centred initially around some mines acquired from one Elizabeth Tuke a member of another Quaker family. Edward Pease (1767-1858) was the man who started the railways thereabouts, initially the world famous Stockton-Darlington Railway, to develop which he hired famous Tyneside engineer George Stephenson.

In the nineteenth century Joseph Pease and Partners developed model, colliery villages at Esh Winning and Waterhouses. Allied with this core provision, where the houses in the two villages were more substantial than those of other colliery settlements, attention was given to drainage and sanitary conditions. The family also took interest in the education and welfare of its workforce. (Durham Memories, (2009) The Northern Echo)

Not only did the Peases want the houses in the two villages to be more substantial than those of other colliery settlements they also, unusually, provided each house had a large garden for growing vegetables and fattening pigs. Joseph Pease (1772-1846) became the first Quaker MP to represent the town and was an active player in the movement to enact anti-slavery legislation. A statue commemorating that fact still stands just below High Row opposite the market. A school (Arthur Pease County Primary) carried the family's name until the 1960s.

Of course life is not always smooth and the 1920s recession saw more difficult times for the mining part of the empire, leading to cutbacks and accusations by workers of disloyalty by management but it is beyond doubt that the Peases' business activities had a profound and socially sensitive (by nineteenth century standards) impact on the town of Darlington. The choice of the words "socially sensitive impact (by nineteenth century standards)" was made with care. We have suggested that the Peases were broadly a force for good in Darlington and environs but there were and are commentators who want to take a swipe at them. [O'Donnell (2009) reports that The Times ran a piece in 1838 to argue that Joseph Pease's employees suffered miserable working conditions in the UK even as he argued against slavery in the colonies (what price political commentary!); and Sutherland (2008) seeks to belittle those parts of the Pease tribe engaged in the twenty-first century City of London.] Perhaps the point was or is that no ordinary mortal is perfect. Thus our argument is not that the Peases were without blemish in all their activities across the full breadth of the extended family but simply that they did a fair measure of good in and for Darlington and mid-Durham (Esh Winning lies nearer 
Durham City than Darlington) and that social good was driven by their Quaker principles. The local football team Darlington FC, founded in 1883, is still to this day proud to be known as 'The Quakers'.

Hence, in all three of these Quaker based cases, we see examples of family businesses which actively pursued SRM, with one of their key motivators for such a benevolent pathway being the Quaker, Christian beliefs of the families. Setting their actions in the context of the times, when abuse of labour (be it by paying low wages, working people excessively or in poor and dangerous conditions) for the benefit of mine, mill or factory owners was a commonplace, we may see the actions of these Quaker firms as the pursuit of an ethically rooted CSR agenda as a foundation for their businesses.

\section{A Jewish Firm - Pearl Paints}

Pearl Paints Ltd. was a South Walean firm, which sadly no longer exists: it went into receivership in 2003 and was bought from the receiver by Spencer Coatings Ltd., a private company based in Aberdeen which consolidated all production at its Aberdeen plant. Spencer is a company which specialises in industrial coatings, serving special markets such as coatings for pipelines and off-shore oil platforms, as well as more general industrial clients. Its acquisition of Pearl in 2003 was part of a programme of acquisitions of specialist producers aimed at leveraging their then current organic growth. Spencer Coatings Ltd. is the largest coatings manufacturer in Scotland.

Pearl was a Jewish owned, family firm which made paints and varnishes. It established in South Wales in the 1930s in the Treforest Estate, Pontypridd, near Cardiff. It was founded by three Jewish brothers, Simon, Fritz and Willi Stern who left Fulda in Germany in the mid-late 1930s (for the obvious reasons, as Hitler's Nazis abused Germany's Jews). The brothers also brought with them two, Jewish non-family members, chemists, to help to start their new paint business in the UK. They went to South Wales in part because there was Government support available because the area was economically depressed. The Treforest Estate was established under the terms of the Special Areas Act (1934), a government initiative aimed at combating the growing unemployment and decline in traditional heavy industries. Because initial enthusiasm from domestic, UK companies was at best muted, the notion of opening such estates to refugee businessmen was realised, Parry-Jones (2014). As a result, the Sterns set up their plant in Treforest where they benefited from grants and ambient infrastructure. By June 1939, sixtythree companies had taken premises on the Treforest Estate, of which thirty were owned by Jewish refugees from Austria, Czechoslovakia and Germany, according to the Jewish Chronicle (1939a). Indeed the practice of employing local labour on the Treforest Estate (not only by Pearl) was one of the positive facts to elicit praise from the then Prime Minister, Neville Chamberlain, during a visit in June 1939. He is quoted as saying that the industrial estate was, "one of the most heartening things I have ever seen in Wales. There are quite a large number of people there all employed upon new industries for Wales, some of them brought by people who have had to leave their own countries [including the Sterns, author's note]." - Jewish Chronicle (1939b). Perhaps the point to emerge is that Jewish-Welsh relations may have had their lower moments in the early twentieth century but Treforest was a beacon of good practice and optimism.

The availability of government support was expedient for the Sterns as they established Pearl Paints but the key ingredients of managerial and technical know-how came with themselves and their Jewish German chemists. Beyond that the firm employed local Welsh 
people who were in general non-Jewish. The company was small in scale at the outset employing only a few people and, even once it became established and grew, it typically employed no more than about fifty people.

This firm like our other case examples had ethical underpinnings to its activities, based on the Jewish faith in this case. The Stern brothers sought to maintain something of a sense of family within the firm, the religious divide between themselves and most of the workforce notwithstanding. In terms of understanding what may be good management practice this may sound unremarkable but it had been alleged by some that Jews, even Welsh-born Jews, were not always made as welcome in Christian, non-conformist Wales as one might have hoped, Parry-Jones (2014). Hence a bonding or brotherhood of men within this Jewish owned company can be seen as evidently desirable, but not necessarily a foregone conclusion in the wider South Wales community. No doubt the fact that a positive lead came from the Jewish owners was seen in a positive light by the employees. Wages in the firm were not exceptional but, in the period immediately after the 1930s depression, steady wages for reliable work were a matter of reassurance for those whom the Sterns employed. There was in short a coalescing of interests between owners and employees. The owners were grateful both for the sanctuary afforded to them by Britain and also for the benefits afforded to their new enterprise under the Special Areas Act (1934). The employees were in turn grateful for the very fact of employment, in an area of Wales which had experienced economic privation, and for the supportive, 'extended family' working environment in which they worked.

We conclude with the following anecdote which is symbolic of the Sterns' approach to their staff. It was decided that there should be a 'do' for the staff as a kind of thankyou. It was decided to have a Christmas lunch, which perhaps axiomatically served non-kosher food: it was after all a Christmas lunch! The family however, being practising Jews, felt that they couldn't eat this non-kosher food but they felt that they should attend the event to demonstrate their togetherness with the workforce. What to do? They attended the lunch and took along their own sandwiches to eat, while the staff enjoyed their festive fare! Thus honour was satisfied on all fronts and team spirit was enhanced.

\section{A UK, Muslim Firm - Noon Products}

Finally we look briefly at two Muslim owned firms, one British and one Malaysian. The first is a food production company based in West London, Noon Products. This was a key constituent of the business group controlled by the late Gulam Noon, a Muslim, Indian immigrant to Britain. His family were Muslim sweet makers of relatively modest means in Bombay. A young Noon came to Britain to try his luck, at a time when access to Britain was open to all Commonwealth citizens, and started a sweet making shop in Southall, West London, initially, in February 1974.

His big move arguably was the founding of Noon Products in 1987 (still in the Southall environs) which made pre-prepared, Asian meals. His main business was as a supplier of others' own brand produce (e.g. Sainsburys) and airline meals for major, long-haul carriers. The business flourished and eventually was sold to Kerry Foods, an Irish company in 2005, although Noon retained a stake in the enlarged business. He also had various other interests including being a Director of Noon Consultancy Ltd.. As recognition of his contribution to British industry and its society he was knighted and then made a Lord in 2011.

Reading his autobiography, Noon (2008), it seems clear that he is trying to tell a tale of a business story which he would have us believe has its roots in "doing things the right way" 
and respecting those with whom one has dealings, be they employees or customers. A particular story which resonates with the theme of our paper is an incident in 1998. As he drove back towards and neared his plant in Southall one day, he was surprised to see a pall of smoke. His industrial scale cooking premises were ravaged by a fire - a fire against which his insurers would prove loth to pay out. The next day, his 250 workers looked on miserably at their ravaged plant and probably expected to be laid off forthwith. How could he afford to do otherwise?

This was not what actually happened. He states in his autobiography, Noon (2008, p.73), that his auditors/advisers told him that he should make the staff of the Uxbridge Road plant redundant but he declined so to do because "[he] would soon be needing their help". Thus, as he puts it (p.72), he 'stood by' his staff. He also explains that David Sainsbury, with whom he had developed strong links as a key product supplier, offered to take any surplus staff on to his own staff pro tem, until Noon Products should need them again. Sainsbury is recorded as also introducing him to another food producer (with a plant in Wrexham) to whom he could subcontract production until his own facility could be reinstated.

Noon's action in not ditching his, temporarily redundant, employees cemented a bond between him and them, reports Andrew Davidson (2008) in a Management Today Interview. Quite simply this seems to be ethically based management of the best kind rewarded by loyalty from staff who appreciated that they had been extremely sensitively handled. Were the actions also faith rooted? Since Noon claims that his faith is important to him, it seems reasonable to speculate that the answer is yes. Moreover, it is, at the minimum, somewhat reassuring as to the human condition, that a Jewish controlled firm should step forward to try to help a trading partner, which was Muslim controlled, in its time of need.

\section{A Small Malay Muslim Firm - Safis Solutions}

Safis Solutions began life in 2011 as a management buyout, by the MD and his brother, of the Penang based IT division of Sapura Holdings, a Malaysian conglomerate. It is a small business incorporated as a private limited company, run by its effective owner and founder Md. Fadzil Ali, a Malay in his mid-forties. It employs 12 people and specialises in IT security hardware. Its customers thus far are all firms operating in Malaysia but these include companies with Taiwanese and Indonesian parents and hence cross-cultural elements in their dealings.

As his name suggests, Mr. Ali, the MD, is a Muslim and he tries to incorporate his belief in Islam into the way in which he runs the business. Interestingly, however, Mr. Ali freely admits that he was not always a pious Muslim (pious was his word and correctly means 'devout' but I might tend to choose another word or phrase such as 'committed' or 'strongly observant', because pious can have a slightly negative connotation). In his younger days, he observed his faith more casually and enjoyed a glass, or two, of the Irish elixir known as Guinness. His drinking days are now gone but he explained, en passant, that there is, or can be, false piety within the Muslim community which is ultimately unhelpful, especially when one considers how non-Muslims may see that faith. This strikes us as an important point in what is a multicultural country such as Malaysia, especially in Penang province, where the Muslim and nonMuslim populations are close to 50:50. Interestingly, one of his key employees is a Chinese Malaysian lady who acts as the Sales and Operations Manager.

Given our theme in this paper, the key issue is in what ways does Mr. Ali's Muslim faith inform the way in which Safis is operated. Three aspects come to mind. The first is the very origin of the business. In 2010 Sapura decided that it would close down its IT-security division 
in Penang. Mr. Ali, buoyed by his newly strengthened faith felt moved to ask if he might buy the division, in part using his redundancy package, and take over the existing staff. This request was agreed to by Sapura and the outcome gave Mr. Ali himself a continuing career and kept a dozen or so others in employment. He felt he was making a real contribution to the local community and thus far the business has thrived.

In terms of rewarding staff, Safis policy is to pay competitive wages plus bonuses sculpted to the different subgroups of employee. For the technical staff, who work in small teams (usually two or three), there are individual bonuses plus project bonuses for timely completion of projects to standard (but no overtime). The Chinese lady and one other Chinese employee normally get two bonuses, Hari Raya (or Eid Mubarak) at late summer and at the calendar New Year (a tolerable proxy for the Lunar New Year). Hence there are incentives tailored to both the work and cultures of different employees. In addition Safis pays $50-75 \%$ of a health plan chosen by the individual employee. This is in addition to paying Government Social Fund contributions, as required by law. Finally, Mr. Ali funds an annual staff trip or group outing this could be perhaps a mini-break in Langkawi (an island resort north of Penang).

A third vignette appears to reinforce Mr. Ali's sense of obligation to society. Subsequent to Safis becoming established in its new form, an offer to take it over was received but was refused. Mr. Ali believed that he would do more good by continuing to run it as his own business. As he put it, "If I help others, maybe others [not necessarily quite the same others: author's annotation] will reciprocate." An ethical approach to business may, perhaps should, reap its own benefits.

In the longer term, Mr. Ali hopes that he can keep Safis running in good heart and that one or more of his children may feel moved to join the family firm at some point in the future.

\section{Discussion and Conclusion}

In the descriptions of all seven of the firms above, there are two clear, basic, common themes. They are, or were, all firms in which families held the managerial reins and all had a core, ethical thread to their management, which led them to behave towards their workers and the wider communities in which they were located in a socially responsible manner. Not only was this thread present in all the firms we have described but one can also say that it was built into their very fabric or to put it another way it was part of the foundation on which these micro-economic entities were built. Whilst one sees the socially responsible built into the foundations of the businesses, on the other hand all were businesses which operated, or continue to operate, in a profitable fashion. That is, one can say that they operate in accordance with standard neo-classical economic precepts subject to certain, key socially responsible constraints.

The socially responsible underpinnings of these firms can further be thought to illustrate a model behaviour of what, in modern terms, would typically be described as CSR activities being built in to the core fabric of businesses rather than being an add on feature, as is all too often seen to be the case - the attitude being that such add-ons are desirable, especially in terms of regulatory conformance and P.R., but they are not deeply embedded into the core of the business.

The third point of interest to emerge from the cases is that the families which ran or run them are all exponents of one of four different religions (we perhaps loosely refer to Buddhism as a religion in this context) and all of them appear to believe that their beliefs helped and 
sustained them. These beliefs were part of their rationale for building socially responsible features into the backbones of the businesses.

Finally, another point which has emerged, as already noted, is that all these firms do seem to operate or were operated in a fashion which can reasonably described as 'ethical'. This surely is what 'business ethics' means by definition. Hence, a spin-off of the central argument is that 'business ethics' does exist; or to put it the other way about the sceptics who claim business ethics is an oxymoron are wrong.

From a methodological perspective, our conclusion can best be described as an important conjecture based on some initial, empirical underpinnings (the case evidence); it is not an empirical verification of a prior hypothesis as in the positivist view of the world.

The applicable message for other businesses which recognise the need to be seen to have a coherent CSR agenda is that such an agenda very much can be more than an add-on feature. It can be an integral part of the company's overall business philosophy, and while there may be some 'additional costs' associated with such an enlightened view it is by no means inimical to making a perfectly decent level of profit. However, our conjecture is that family control is the key because it allows the owners, if they so wish, to operate a multi-attribute utility function consonant with their faith beliefs and/or ethical posture: but, that does not mean that nonclosely controlled firms cannot do the same things, if the will exists.

The case firms above varied in size from small, through medium to large but even the large firms were family controlled or directed at the point in their history highlighted in the case description, although it is becoming increasingly rare for big companies in the UK to be family-run - this is less true in some Asian markets. Two of our case firms, Cadburys and Rowntree, have now been absorbed by foreign multinationals and frankly may have lost some of their SRM sparkle as a result! For example, when US company Kraft effected a hostile takeover of Cadburys in 2009, they promised that no major UK production centres were at risk. Within a few months they were busily reneging on that undertaking and closing a large factory with the loss of several hundred jobs, not much regard for SRM there.

Acknowledgements I am grateful to Leonard Minkes, for introducing me to the Pearl Paints story and for comments on an early draft of this paper; and, to the owners of Tang Mo and Safis Solutions for their stories.

Open Access This article is distributed under the terms of the Creative Commons Attribution 4.0 International License (http://creativecommons.org/licenses/by/4.0/), which permits unrestricted use, distribution, and reproduction in any medium, provided you give appropriate credit to the original author(s) and the source, provide a link to the Creative Commons license, and indicate if changes were made.

\section{References}

Allinson, R.E. 2008. The foundations of business ethics. In Corporate and white collar crime, ed. J. Minkes and L. Minkes. London: Sage.

BBC. 2014. Clothes to die for. This World (documentary), BBC2, 21st July, 21.00.

Beekun, R.J., and J.A. Badawi. 2005. Balancing ethical responsibility among multiple stakeholders: The Islamic perspective. Journal of Business Ethics 60: 131-145.

Bowen, H. 1953. Social responsibilities of the businessman. New York: Harper and Row.

Campbell, R.H., A.S. Shearer, and W.B. Todd, eds. 1976. An inquiry into the nature and causes of the wealth of nations, A. Smith, 1776. Oxford: Oxford U.P.

Carroll, A.B., and K.M. Shabana. 2010. The business case for corporate social responsibility: A review of concepts, research and practice. International Journal of Management Reviews 27 (5): 85-106.

Clegg, S., C. Carter, M. Kornberger, and J. Schweitzer. 2011. Strategy - Theory and practice. London: Sage.

Collins, J.W. 1994. Is business ethics an oxymoron? Business Horizons 37 (5): 1-8. 
Collis, J., and R. Hussey. 2003. Business Research: a practical guide for postgraduate and undergraduate students. 2nd ed. Basingstoke: Palgrave.

Companies Act, UK. 2006. http://www.legislation.gov.uk/ukpga/2006.

Cyert, R.M., and J.G. March. 1963. A Behavioural theory of the firm. New York: Prentice-Hall.

Davidson, A. 2008. The MT interview: Sir Gulam Noon. Management Today, Thursday 27th November.

Durham Memories. 2009. Built on the strength of the mining industry. The Northern Echo, 30th January 2009 Online. http://www.thenorthernecho.co.uk/news/4089672.Built_on_the_strength_of the_mining_industry/.

Fitzgerald, R. 1999. Employment relations and industrial welfare in Britain: Business ethics versus labor markets. Business and Economic History 28 (2): 167-179.

Friedman, M. 1962. Capitalism and freedom. Chicago: University of Chicago Press.

Halmos, P.R. 1960. Naïve set theory. New York: Van Nostrand.

Hodgson, G.M. 1993. Institutional economics: Surveying the 'old' and the "new". Metroeconomica 44 (1): 1-28. Jewish Chronicle. 1939a. Issue 9th June 1939.

Jewish Chronicle. 1939b. Issue 30th June 1939.

Lin, L.-W. 2010. Corporate social responsibility in China: Window dressing or structural change. Berkeley Journal of International Law 28 (1): 64-100.

Lynn, M.L., M.J. Naughton, and S. Vandeer Veen. 2010. Connecting religion and work: Patterns and influences of work-faith integration. Human Relations 64 (5): 675-701.

Marshall, A. 1890[1920]. Principles of economics. 8th ed. London: Macmillan.

Morland, Leigh. 2009. Cadbury's. Case Study, University of Huddersfield. Unpublished. http://eprints.hud.ac. uk/12399/.

Noon, Sir Gulam. 2008. Noon with a view: Courage and integrity. Dunbeath: Whittles Publ.

O'Donnell, Elizabeth. 2009. There's death in the pot: The British free produce movement and the religious Society of Friends, with particular reference to the north-east of England. Quaker Studies 13 (2): $184-204$.

Parry-Jones, C. 2014. The history of the Jewish Diaspora in Wales. PhD Thesis. Bangor University, North Wales. Platts, J. 2014. Achieving motivation, not utilitarianism. The Friends Quarterly 42 (1): 33-43.

Prayukvong, W., and M.J. Foster. 2014. Buddhist economics meets corporate social responsibility. International Journal of Economics and Business Research 8 (2): 175-192.

Raphael, D.D., and P.G. Stair, eds. 1978. The theory of moral sentiments, A. Smith, 1759. Oxford: Oxford U.P.

Rowntree \& Co: Chocolate Manufacturers, History of York. 2014. http://www.historyofyork.org. $\mathrm{uk} /$ themes/victorian/rowntree-co-chocolate-manufacturers.

Schumacher, E.F. 1973. Small is beautiful. London: Blond and Briggs.

Sharma, P., J.J. Chrisman, and J.H. Chua. 1997. Strategic management of the family business: Past research and future challenges. Family Business Review 10 (1): 1-35.

Simon, H.A. 1955. A behavioral model of rational choice. The Quarterly Journal of Economics 69 (1): 99-118.

Sorenson, R.L., K.E. Goodpaster, P.R. Hedberg, and A. Yu. 2009. The family point of view, family social capital and firm performance. Family Business Review 22 (3): 239-253.

Spence, L.J., and R. Rutherfoord. 2001. Social responsibility, profit maximisation and the small firm ownermanager. Journal of Small Business and Enterprise Development 8 (2): 126-139.

Stiegeler, S.E., and G. Thomas. 1976. A dictionary of economics and commerce. London: Pan Books.

Sutherland, Ruth. 2008. Trouble at house of Pease. The Observer. Sunday 7th December.

Transparency International. 2014. The corruption perceptions index (CPI) - 2014. Germany. http://transparency. de/documents/cpi/index.html/.

van Witteloostuijn, A. 2016. What happened to Popperian falsification? Publishing neutral and negative findings: Moving away from biased publication practices. Cross Cultural \& Strategic Management 23 (3): 481-508.

Yin, R.K. 1994. Case study research: Design and methods. Beverly Hills: Sage.

Zairi, Md, and J. Peters. 2002. The impact of social responsibility on business performance. Managerial Auditing Journal 17 (4): 174-178.

M. John Foster is an Emeritus Fellow of the Faculty of Business and Law at Kingston University, in London; before that he was its Associate Dean for a decade and founded the Faculty's Asia Business Research Centre. Current research interests embrace: the effectiveness of strategic planning; evaluation processes for FDI; and business in China and South East Asia. He has published in a wide range of journals of international standing. He has been a Visiting Professor at universities in both China and Thailand and has undertaken consulting assignments for major firms in the private sector, the UK's Audit Commission and educational establishments in the UK and overseas. 